TURIZAM

Volume 22, Issue 3

84-94 (2018)

ORIGINAL

SCIENTIFIC PAPER

\title{
Restrictions or possibilities? - Visitor management in the Börzsöny landscape unit of Danube-Ipoly National Park (Hungary) (1)
}

\author{
Borbála Benkhard ${ }^{\mathrm{A}}$, Réka Előd ${ }^{\mathrm{B}}$, Katalin Martonné Erdős ${ }^{\mathrm{A}}$ \\ Received: May 2018 | Accepted: September 2018 \\ DOI: 10.5937/turizam22-18798
}

\author{
nné Erdős ${ }^{A}$
}

\begin{abstract}
The objectives of this paper is to survey the touristic infrastructure, services and regulations in the Börzsöny Mountains not far from Budapest and to define those measures that can be considered as visitor management tools. As a result the implementation of such visitor management methods may become more effective and strategic. All factors involved in the survey had been collected on field examinations and through personal interviews with the specialists of the two most important touristic organisation of the area (national park and Ipoly Forest cInc). Potential advantages had been defined accordingly to references and on our previous surveys. After the aggregation of measures and tools that can be considered as visitor management methods, it has been determined that besides creating more awareness of the benefits of those, we need to put more emphasis on informing visitors and the application of tools supporting the adherence of restrictions. Accordingly, we expect that further to protecting attractions there will be less conflicts.
\end{abstract}

Key words: visitor management, protected area, education and interpretation, behaviour of tourists

\section{Introduction}

The desire to discover protected areas and the number of recreational visits in natural environment are growing globally. Therefore, it is increasingly important to focus visitor management on protecting the attractions and values. While there are substantial results in this area considering the theoretical foundations, research background and practical execution in several countries of the world (Leung et al., 2014, Pickering et al., 2018), strategy development, deliberate application of methods are not at all at full scale within the protected natural areas in Hungary (Benkhard, Martonné, 2018).

A University of Debrecen, Department of Landscape Protection and Environmental Geography, 4010 Debrecen, Egyetem tér 1. Pf. 9. Corresponding author: benkhard.borbala@science.unideb.hu

B Danube-Ipoly National Park Directorate, 1525 Budapest, Pf. 86. Hungary 
The picturesque Börzsöny Mountains that we would like to review is lying at $70 \mathrm{~km}$ North Budapest and very popular among hikers. Tourism management of the area that belongs to the Danube-Ipoly National Park has several specifics. Destinations had been explored and the popular tourist trails had been formed much earlier than the area received legal protection. Rules for nature protection and the interests of the state forestry, as the primary manager of the mountains covered by forest inevitably collide with each other and with the tourists. Therefore harmonized visitor management would be highly important.

In this paper the way how visitor management measures applicable to natural areas are used in the Börzsöny is outlined and the reasons of their introduction is discussed. Problems and disadvantages of legal regulation and also the unutilised advantages of visitor management measures are analysed. The present paper aims to suggest that most conflicts could be avoided with measures applied consciously and appropriate communication would help keeping them.

\section{Visitor management in natural areas}

The visitor and the service provider are found in the focus of traditional visitor management strategies and methods (Pearce, Dowling, 2018). Their aims are: intensify visitor experience, develop products and differentiated services corresponding to the demand, increase income via increasing the reputation and respect of the attraction, reduce seasonality (Rátz, 2011). In contrast, Eagles et al. (2002) emphasize that in the case of protected areas the aim of visitor management is to handle problems raised by the great number and the increasing activity of visitors in harmony with other strategies related to the area. The primary aims and characteristics of this type of visitor management strategies are the following:

- to control (the visitor behaviour),

- to influence (visitor decisions),

- to reduce the effects of visitors on the environment.

Several publications describe the method of the selecting applicable tools from scientific analysis (Newsome et al., 2001; Eagles et al., 2002) through practical handbooks (Cole et al., 1987; Phillips, 2002; Manning et al., 2017) and general guidance available online providing brief orientation all the way to brochures linked to local strategies (Swedish EPA, 2015, TRC, 2014).

Newsome et al. (2001) in the course of typifying the studied (visitor) management methods considered the mechanism of the effects of these methods on the visitors (direct or indirect) and the subject of management (site or visitor). Manning et al. (2017) established a matrix based on the strategies limiting usage (e.g. legal regulations) and the occurring problems (e.g. negative effects on resources). In the 2010 guidelines of IUCN (Leung et al., 2014) management strategies are classified into 4 categories based on whether they influence demand or supply, or regarding these two as fix they aim to reduce harmful effects via changing visitor behaviour or enhancing the 'resistance' of parks and protected areas.

In this paper the classification of Newsome et al. (2001) is used as a base with the note that all measures suitable to influence visitor movement, behaviour and thus their effects on the area are called visitor management measures. As a result, measures related to the location and treatment of establishments called site management by Newsome et al. and are discussed as visitor management measures in this paper.

Apart from the general processes the ideal methods depend on the specifics of the area (natural, cultural, social). Often regulating visitors, reducing harmful effects are not consid- 


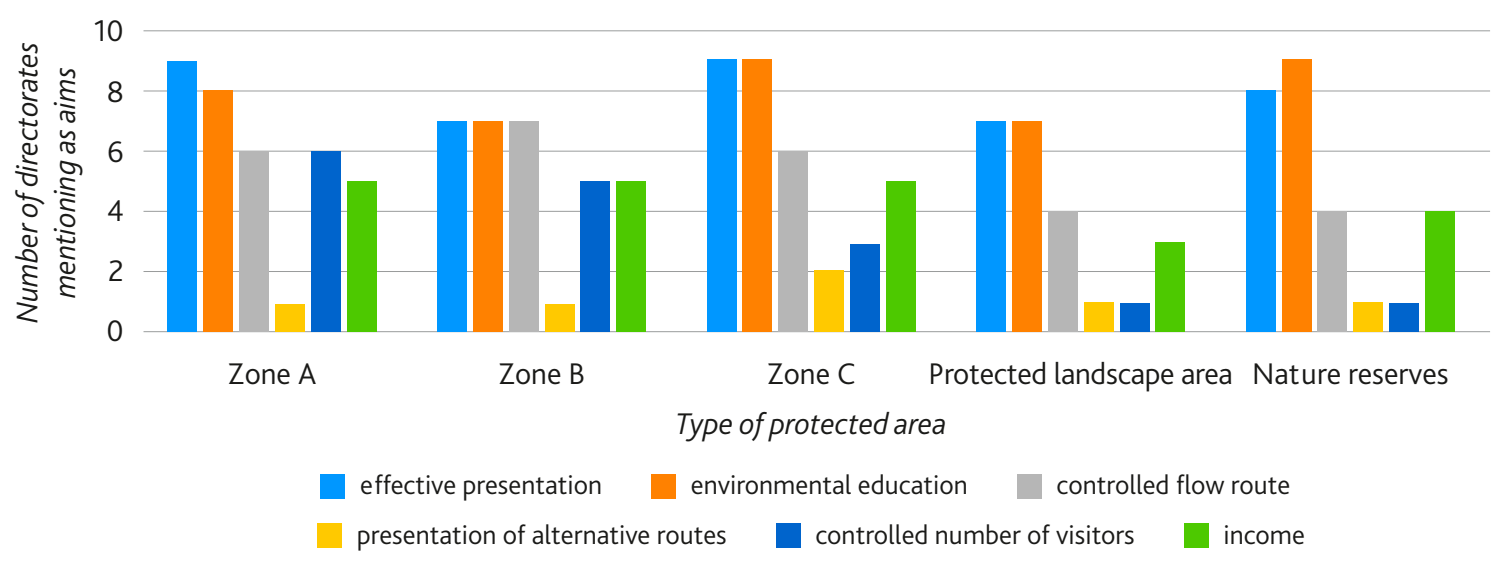

Figure 1. Aims of planning tourist routes guided by national park directorates (10) (Benkhard, 2016)

ered when activities, limitations, supply or interpretation elements that could be regarded as visitor management measures are introduced because their usage in this way is not known. For example, one of our earlier research (also examining the aspects of establishing a nature trail) discovered that when guided tours are planned by national park directorates in Hungary the possibility of presenting alternative tourist routes to visitors is not really (Figure 1) considered (Benkhard, 2016).

The Börzsöny area presented in this paper had been a protected landscape between 1978 and 1997 and since it is part of Danube-Ipoly National Park (henceforward DINP). Forestry and tourism in the area producing significant economic profit have a longer history. It is apparent that the three aims and activities have to be harmonized in order to preserve values, to achieve reasonable and sustainable land use and to meet the demand of the society.

\section{Tourism and regulations}

Considering deliberate management activities information boards and direction signs appear first in an ideal case (Eagles, McCool, 2004). Personal presence of the manager's representatives (e.g. rangers) may become necessary after this. And the third step is represented by regulations. In Hungary these activities developed in different order. Hungarian national parks became destinations for tourists gradually and in a grade differing from each other (Michalkó, 2003). The number of visitors in mountain areas was already relatively high prior to giving protection (from the early 2 oth century) to the areas mostly thanks to hikers. In contrast, in lowland areas visitors started to turn up after the national park status was obtained.

Priorities and allowed activities are different in areas with different grade of protection (Leung et al., 2014, Eagles et al., 2002). According to Act LIII of 1996 on Nature Conservation in Hungary (henceforward ANC) one of the primary tasks of national parks is to help recreation. This can be carried out in different ways in zones A, B and C. For tourism, i.e. "participation of the public in the protection of nature" national parks established a kind of tourism superstructure. The law for the protection of the given area contain further and more accurate regulations (in harmony with other regulations). Unfortunately there is no visitor management plan set for the Börzsöny area yet. Once completed, it will has to be integrated in the forestry and protection management plans. 
Woodlands in the area of DINP are protected areas. Moreover, they are part of the Natura200o network thus based on $\mathbb{S} 22$ and 24 of Act 37 of 2009 on forests, the protection and management of forests (henceforward AFP) their primary role is for protection. According to chapter (3) of $\mathbb{S}$, in this area the regulations of AFP have to be applied with the difference contained in the act on the protection of nature. Apart from these AFP mentions $(\mathbb{S} 93)$ tenting, establishing tourist routes, tourist equipment and their operation and sport event as well.

Increasing strength of Hungarian tourist campaign, exposing values in Hungarian mountains, their description in visitor guides and creating sign posts on the trails leading to them took place way before their designation as protected values or areas. Establishment of protected areas and the introduction of regulations affected an already established and developed tourist trail network and popular destinations generating tension. Information on the regulations and information on the reasons behind the regulations were given even later and cannot be regarded as full even today. Furthermore, the number of nature protection guards in the national parks is very low thus each guards has to cover a huge operational area therefore visitors hardly meet them during their trip.

\section{Tourism in Börzsöny}

Börzsöny near the capital $(\sim 60 \mathrm{~km})$ is a popular hiking place that can be easily accessed from several directions. Its highest point, Csóványos is $938 \mathrm{~m}$ high and hiking in this low mountain requires no special equipment or training. The study area of the present paper is bordered by the following settlements in the Börzsöny: Kóspallag-Szokolya-Nógrád-Diósjenő-Nagyoroszi-Bernecebaráti-Kemence-Perőcsény-Nagybörzsöny-Márianosztra.

Until the early 2oth century not many people went into the mountains while nowadays visitors like this area. However, it is still not overcrowded except for Királyrét at the southern edge of the mountains. Popularity of the central area of Börzsöny can be explained by the possibility of hiking over a $100 \mathrm{~km} 2$ forest covered, public road free and settlement free area exposed well by tourist trails. The lack of public roads in the centre of the mountains is because same forest owners did not allow hiking in their private forests in the first half of the 2oth century (Kertész, 2014).

The common characteristic of the tourist products and activities found currently in the area is the natural environment. Considering the ways of transport (giving the basis for most of the regulations) and the type of movement the following permitted activities either individual or in groups can be identified: hiking in nature on foot, cross-country running, cycling, horse riding, skiing and fishing.

In most parts of the Börzsöny forestry is performed by a state company (Ipoly Forest cInc. henceforward IF). Considering the utilization of woodlands apart from an income from timber industry the role of recreation, tourism and cultural possibilities among non-marketized forest services apart from income from forestry (Ministry of Agriculture, 2016).

\section{Visitor management measures applied in the Börzsöny Landscape Unit of DINP}

We have summarized (Benkhard, Martonné, 2018) the potential benefits of the application of visitor management tools at protected areas in Hungary based on literature (Eagles et al., 2002; Eagles, McCool, 2004; Newsome et al., 2001; Pénzes et al., 2008; Puczkó, Rátz, 2000), and the 

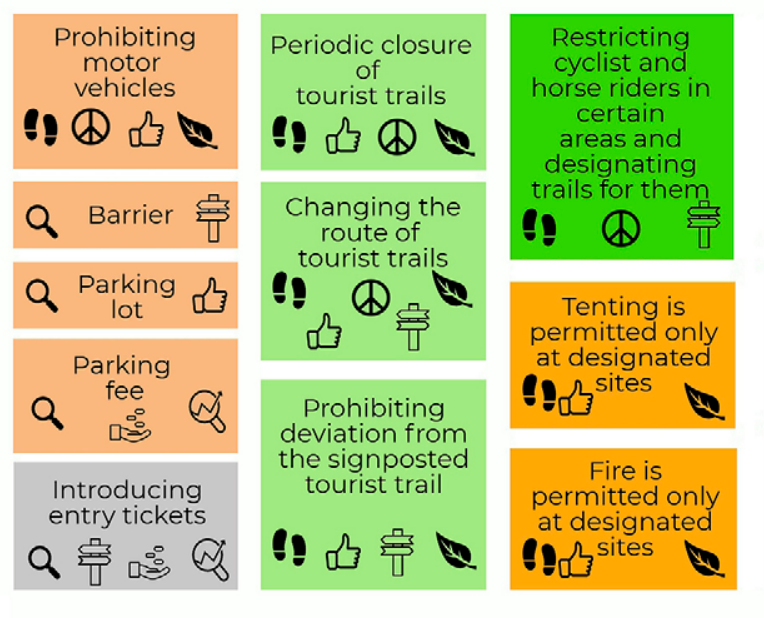
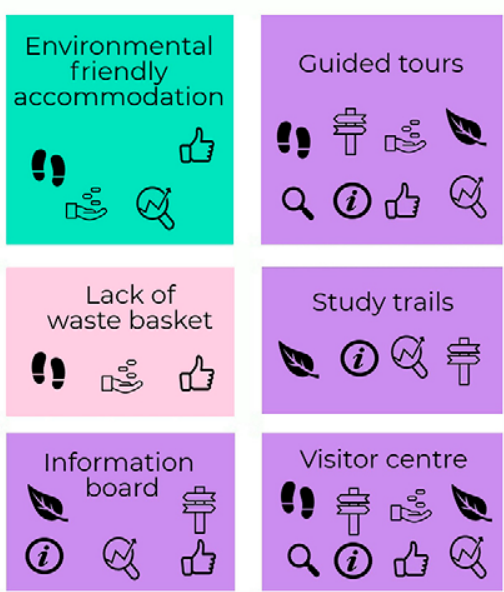
Q8 reducing load
Q visitor monitoring
:
$\$$ protection of values
呂 directing visitor flow
marketing measure
Q $\begin{aligned} & \text { avoiding conflicts } \\ & \text { from common use }\end{aligned}$
$\alpha$ influencing visitor
(i) information

Figure 2. Potential advantages of visitor management measures used in the Börzsöny (own source, based on Benkhard, Martonné, 2018)

experience of ecotourism experts and rangers. The ones can be observed at the Börzsöny area is shown on Figure 2. We have collected and analysed the benefits together with the tourism experts of the area by deep interviews. Online and printed literatures introducing the Börzsöny area and the analysis of touristic brochures have also contributed to establish our database.

Visitor management measures suitable for controlling, influencing visitors and avoiding or reducing negative effects used in the study area are discussed in the following. It is worth noting, however, that their potential is much wider than used currently.

Newsome et al. (2001) regard the establishment of various zones the key to visitor management techniques. The definition of zones of a certain area depend on the primary utilization of the area and the activity and aims of other stakeholders. These zones are not necessarily the same as those recommended by IUCN. For the Börzsöny and DINP, however, no official zones have been formed yet (neither IUCN zones nor other division from management point of view).

\section{Locating facilities and services}

Regarding site management measures the most obvious is the location of facilities and services. One of the most important attractions of Börzsöny is its romantic picturesque character which is basically maintained by the fact that there is no public road network in it. Although the area of Central Börzsöny is crossed by three (NE-SE oriented) forestry roads partly opened to the public (Figure 3) their traffic is not significant. The busiest road entering the mountains deepest runs across Szokolya to Királyrét. Further access is prohibited by gates. At Királyrét 
there are (pay) car and coach parks. Normal railway runs on the eastern side of the mountains while narrow gauge railways run into the mountains as well. Out of the former $200 \mathrm{~km}$ network today $\sim 37 \mathrm{~km}$ is still in use to transport tourists.

In the area of the Börzsöny belonging to the national park an $\sim 300 \mathrm{~km}$ long signposted tourist trail network has been created. Wandering off paths is prohibited in strictly protected areas (ANC $\$ 40)$.

For special nature protection reasons (in the nesting period of strictly protected bird species) once a tourist trail was diverted and once signposts were replaced temporarily. The route of tourist trails was modified in 2013 as well by IF in order to avoid conflicts caused by the joint usage of trails by the forestry and pedestrians (Ipoly Erdö Zrt., 2013). At Nagy-Hideg Hill, near the tourist house a row of columns closes the trail from motor vehicles in order to protect grassland on the top of the hill.

A special case occurred in December 2014 when the Pogány-Rózsás Forest Reserve suffered from ice break. According to the regulations (chapter (5) $\mathbb{S} 91$ of ANC) in the area of the Forest Reserve tourists was only permitted on the signposted trails. These trails, however, were inaccessible due to fallen trees. This natural disturbance made forest dynamic studies possible on the one hand (Standovár, 2016), and on the other hand, the development of a more stable and diverse forest was also made possible (Horváth, Bajomi, 2015). Therefore not all of the fallen, broken and dead trees have not been removed and as a result the IF closed the affected trails and warning notices are placed in order to avoid accidents.

Although the Börzsöny is popular among cyclists, this activity is limited to designated areas for the protection of nature, for the safety of cyclists and to avoid conflicts with hikers. Limitations are decided by IF. Accordingly, $65 \mathrm{~km}$ of forestry private and exposing roads marked with cycling tourist signs are offered to the cyclist (Ipoly Erdő Zrt., 2017) (Figure 3). Several tarmacked roads - that are attractive for cycling - are forbidden for cycling of which most cyclist do not know or ignore prohibition and use these roads.

Horse riding is not so characteristic in the mountains yet. This activity takes place on existing trails with the connivance of the land user.

In contrast to hiking, areal dependence is stronger in the case of more service or facility dependent tourist products. Downhill skiing has great traditions in the Börzsöny. Maintained ski tracks and lifts concentrate skiers to the vicinity of Nagy-Hideg Hill (Figure 3). Longer downhill skiing, however, is possible on marked trails down to Királyrét.

Locating visitor centres and study trails together with the route of regularly offered trips are the most effective visitor control and management measures. As a result and for best utilization, visitor centres and study trails are located in the most popular areas in the Börzsöny (Figure 3): e.g. in the vicinity of Királyrét, Diósjenő and Kemence. The only exception is a study trail (Sisa Pista study trail) in the centre of the mountains which is, however, also easily accessible. Most of the tours guided by DINPD and IF follow signposted tourist trails. Some special tours with a limited number of participants (e.g. lynx sign tracing in winter) may leave the trails. Tours organised by others (like schools, associations, companies) can also follow signposted trails and permit is required only above a certain number of participants.

Accommodation can be found in the inner areas of the mountains as well. These are operated by the national park, the forestry and the private sector as well. Capacity, facilities of and access to the houses in the Central Börzsöny excludes the development of mass tourism and thus significant load on nature. The exception is a four-star hotel with 60 rooms in the inside of the mountains (Nagyirtáspuszta) that can be accessed both on road and small gauge railway. This is an important tourist destination in the SW half of the mountains due to easy access and 


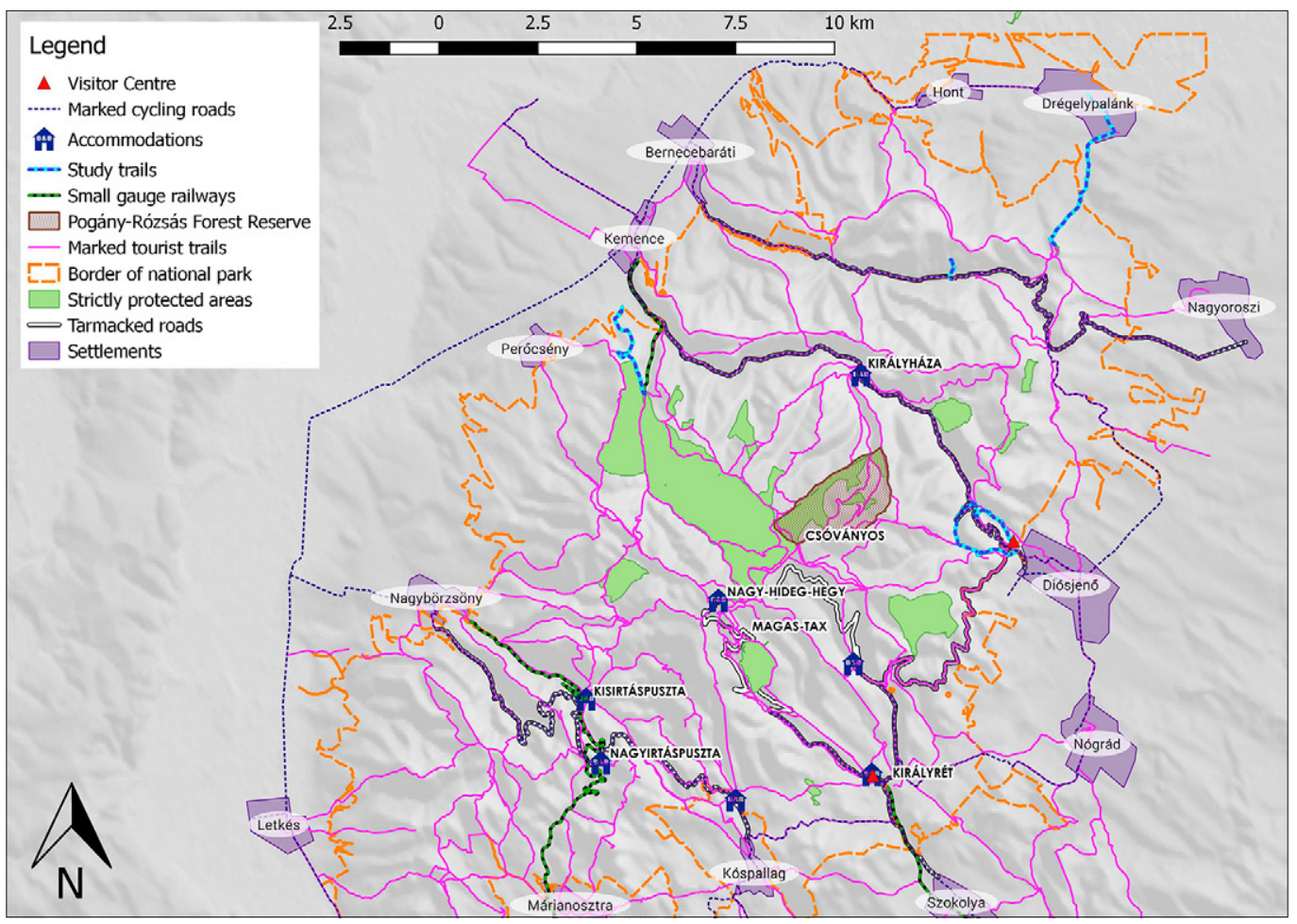

Figure 3. Study area and outdoor possibilities (own source)

services available for non-lodging guests as well (e.g. restaurant, wellness). Tenting is permitted only in the garden of a few accommodation places.

Laying fire is only possible at designated sites for fire that are located outside the DINP or around the accommodation places.

Catering units are few within the national park. The Fekete Valley Pension and the Nagyirtáspuszta Hotel can be accessed by car and small gauge railway from Kemence.

The tourist house at Nagy-Hideg Hill is still one of the most popular destinations among hikers. The other favourite destination is the highest peak of the mountains, the 938 metres high Csóványos where a free lookout tower can be visited, but there are no services available.

\section{Management and characters of facilities and services}

Apart from location the management of facilities and services and their design influence the behaviour of visitors directly and indirectly (as a message) as well. Like the appearance of the built elements fitting in the landscape, authentic building and decorating material are fundamentals of ecotourism. These are realized at most accommodation places in the Börzsöny, however, the type of accessible services could be improved (influencing-limiting water usage, handling waste, utilizing renewable energy resources).

Frequently used facilities during hiking in nature are resting places, shelters. Unfortunately their number is very small and they are unkept. If IF has no financial resources for their renovation and maintenance they are disassembled.

Surface of trails, i.e. the condition of tourist trails determine the possibility of keeping pedestrians on the trail. Widened trails or parallel paths stamped when rounding puddles 
in depressions can be detected at several places, however, surface treatment is not necessary. Eroded surfaces on steep slopes are different. Closing of erosion ditches developed after cutting serpentine roads (with cross laid tree branches), visual highlighting of recommended route (highlighting or marking the edges with a different material, constructing a directing barrier) can be seen at several places. Where height differences can be overcome parallel to the direction of the slope (or warning and directing is useless) steps (material fitting into the environment: using wood, stone) shall be constructed in the trail (e.g. approaching Csóványos from SW). Profile of cycling trails designated by the forestry is mostly tarmac road or dust road. Steep trails or roads covered by crushed stone are not recommended for cycling.

In some cases the lack of certain services and facilities could be management measures. Such is the principle that no waste bins are placed in the area. The idea behind this is that "litter attracts litter" especially as the operator lacks human resources to empty and maintain them regularly. Otherwise the lack of waste baskets has education purpose therefore information tables showing the appropriate behaviour - taking the litter home - are frequent.

The attitude of accommodation facilities to environmental conscious behaviour is variable. There are 4-star wellness hotels to low comfort grade tourist houses. However, low grade of comfort does not mean necessarily smaller environmental impact (e.g. electricity by an electric generator, shortage in sewage treatment). During refurbishment and rebuilding environment conscious behaviour should be considered. With the aesthetic design of the accommodation such resource saving solutions suggests valuable activities and not the renouncing of comfort. Good examples can be found among the developments in the Börzsöny in the last 10 years, however, their number should be much higher (selective waste collection, two-sink compost toilet, flushing toilet with well water).

\section{Education, interpretation}

One of the most appropriate visitor management measures is education and that is emphasized by DINPD and IF as well. The Lynx House serve as the "entrance" to Börzsöny. It has been operated by the DINP Directorate since 1994 and was developed to be a visitor centre in 2014. In the building open every day with a permanent interactive exhibition, guided tours and a study trail starting from the visitor centre. A study trail has been also offered by the Leisure Park at Diósjenő established by IF since 2011 with thematic and on demand tours. Acquisition of knowledge is possible along two further study trails with information tables within the national park.

On Nagy-Hideg Hill the DINP Directorate placed information tables explaining the natural values of grasslands in 2013 (beside the directing barriers that had been placed there earlier to protect the area).

\section{Entrance tickets, fees}

Entrance tickets are suitable to influence the number of visitors at specific places or areas. With differentiated prices they influence the spatial and temporal distribution of visitors and thus tourist load on nature. Entrance tickets on nature protection areas, however, have to be purchased only in the area of the Hortobágy National Park in Hungary. So the peaks of Börzsöny can be visited for free. One of the reasons for this is the fact that neither the selling nor the control of tickets could be solved easily due to the characteristics of the area (easy access from multiple directions, lack of human resources). Secondly, hikers feel that they have the right for free 
access to the forest thus purchasing a ticket to natural areas is the least accepted visitor management measure (respondents in a survey in the Börzsöny gave mark 2 for this in a scale from 1 to 5 ).

Tickets have to be purchased for the exhibition in the Lynx House and to visit the Leisure Park at Diósjenő. Apart from these fees have to be paid for certain programmes and facility or room rental. These tickets are for income and cannot be regarded as visitor management measures.

Considering fees, the most important one is the parking fee at Királyrét introduced in 2007. Parking fees are the second least accepted limitations after entrance fees. Moreover, the number of those who wish not to pay, parking on the grass next to the road outside the parking zone increased. As a result the number of sold parking tickets is not suitable to estimate the number of visitors in the destination. The increasing number of parking tickets, however, indicate that the increasing trend of visitor numbers did not change.

\section{Regulation of usage}

The regulation may affect the number of visitors, the area that could be visited, the time periods when tours are possible or the consumer behaviour of the tourists. In the case of Börzsöny limiting the number of visitors is regulated in the case of organised events (e.g. guided tours, competitions, long-distance hikes) that is prescribed in legal regulations (government decree 275/2004).

Limiting the area to be visited (in the case of hiking, biking and horse riding) has already been discussed. In order to avoid conflicts of common usage forestry roads used for cycling are closed from public cars (with boards and gates occasionally).

When rare and strictly protected birds have nesting time in an area nearby hiking trails are closed or redirected temporarily. Temporary limitation is applied in the case of events as well: night events are limited at some cases to avoid the disturbance of nocturnal animals. In hunting season the visiting of woodlands are limited both in space and time.

\section{Recommendations}

Visitor management measures introduced in natural areas are sensible if:

1. they serve the protection and long-term survival of the values of the area;

2. they have been communicated appropriately;

3. they are acceptable for visitors;

4. their observance can be controlled,

5. in case they are not kept consistent and determined sanctions are made.

For long-term survival the harmony between tourism strategy and realization details is necessary apart from an agreement in the principles. The sense of considering the effects of an investment on the wider surroundings also belong to here. Accordingly those investments where the demands of a certain target group are met and keep visitors in a well-defined area but the type and message of the services are contradictory to the principles of the destination.

The key is the presence of measures and facilities helping the adherence and acceptance of limitations and appropriate information:

- Information on regulations, limitations and the appropriate behaviour. Not appropriate behaviour is in many cases the result of the lack of appropriate information. This is why 
the appearance of information on every possible platform (from information panels via leaflets to home pages and applications) is so important. It is also important to expose the cause-effect relations, i.e. to enable "explanation" to come ahead of limitations!

- Explanation of the necessity and advantages of regulations and limitations. Both prohibitions and the introduced measures could be accepted easier by everyone if their reasons and aims are known.

- Application of supporting facilities. Appropriate behaviour cannot be expected even from the best-meaning people if adherence to the regulations is not helped. This is why significant emphasis has to be given to facilities helping this adherence from clear and visible tourist signs to built elements.

\section{Conclusion}

Neither Danube-Ipoly National Park Directorate nor Ipoly Forest cInc. prepared a complex visitor management plan for the Börzsöny landscape unit of the Danube-Ipoly National Park. Tourism development is determined by adherence to regulations, income increase, inspiring aptitude to nature protection and presenting values. However, the activity, movement and demands of the visitors are modified by the location and design of the facilities and the introduced regulations.

In the Börzsöny areas of different employment can be identified despite the lack of a zone categorisation. The location of the facilities and the route of the tourist products are determined mainly by the network of the already existing public and forestry roads. Apart from physical limits (e.g. accessibility) this is the result of a conscious development and permission activity of the DINP Directorate and IF aiming to form area limits to employment and load.

This, however, also results in many conflicts since many visitors arrive here to hike in the mountains without limits and regulations. Most hikers in the inner areas of the mountains try hard to leave as little imprint on the environment as possible. In case, however, the efforts are not made with the appropriate information and knowledge (e.g. effects of trampling erosion) they cause harm not on purpose. Therefore it is essential to explain the reasons for the regulations and to communicate effectively the advantages of the introduced measures and developments in the future.

\section{References}

AFP 2009. Act No. XXXVII of 2009 on forests, on the protection and management of forests (in Hungarian).

ANC 1996. Act No. LIII. of 1996 on Nature Conservation in Hungary (in Hungarian).

Benkhard, B. 2016. A természeti környezet védelme érdekében bevezetett hazai látogatómenedzsment eszközök. Presentation at a conference VIII. Országos Turisztikai Konferencia, 2016.10.14. Pécs (in Hungarian).

Benkhard, B., Martonné, E. K. 2018. Látogatómenedzsment a hazai védett természeti területeken. Turizmus Bulletin 18(1), 29-36 (in Hungarian).

Cole, D. N., Petersen, M. E., Lucas, R. C. 1987. Managing wilderness recreation use: common problems and potential solutions. Gen. Tech. Rep. INT-GTR-23o. USDA Forest Service, Intermountain Research Station, Ogden, UT, USA. 
Eagles, P.F.J., McCool, S.F. 2004. Tourism in National Parks and Protected Areas. Planning and management. CABI Publishing.

Eagles, P.F.J., McCool, S.F., Haynes, C.D. 2002. Sustainable Tourism in Protected Areas Guidelines for Planning and Management. IUCN Publications. Thanet Press Limited, UK.

Horváth, F., Bajomi, B. 2015. Erdörezervátumok a Duna-Ipoly Nemzeti Park Igazgatóság területén. Cincér Füzetek Különszám (in Hungarian).

Ipoly Erdő Zrt., 2013. Változások a turistautak nyomvonalában http://www.ipolyerdo.hu/hirek/ turaut_valtozas (in Hungarian) (21.07.2014).

Ipoly Erdő Zrt., 2017. Kerékpáros szabályok. http://www.erdeikirandulasok.hu/kerekparos-szabalyok (in Hungarian) (20.12.2017).

Kertész, Z. 2014. Bakancsosok, turisták. In: Bartha, D., Nagy, L., Oroszi, S. (Eds.) Vadregényes erdőtáj - A Börzsöny. Ipoly Erdő Zrt. Balassagyarmat, 483-501 (in Hungarian).

Leung, Y., Spenceley, A., Hvenegaard, G., Buckley, R. (Eds.) 2014. Tourism and Visitor Management in Protected Areas. Guidelines for sustainability. IUCN Best Practice Protected Area Guidelines Series.

Manning, R. E., Anderson, L. E., Pettengill, P. 2017. Managing outdoor recreation: Case studies in the national parks. CABI Publishing, 252.

Michalkó, G. 2003. A fenntartható fejlődés ökoturisztikai aspektusai Magyarországon. Turizmus Bulletin 2003(4), 13-21 (in Hungarian).

Ministry of Agriculture, 2016. Nemzeti Erdöstratégia 2016-2030. Budapest (in Hungarian)

Newsome, D., Moore, S. A., Dowling, R. K. 2001. Natural Area Tourism: Ecology Impacts and Management. Aspects of Tourism. (1st edition) Channel View Publications. Clevedon, Buffalo, Toronto, Sydney.

Pearce, J., Dowling, R. 2018. Monitoring the quality of the visitor experience: An evolutionary journey. Journal of Outdoor Recreation and Tourism.

Pénzes, E., Clarke, A., Formádi, K., Jancsik, A., Madarász, E., Mayer P., Priszinger, K., Raffay, Á., Baráz, Cs., Kelemen, Z., Kevy A., Kopek, A., Pantali, B., Berencsi B., Grubics, M., Károly, A., Lingauer, J. 2008. Országos ökoturizmus fejlesztési stratégia. Pannon Egyetem, Aquaprofit Zrt., Veszprém - Budapest.

Phillips, A., 2002. Management Guidelines for IUCN Category V Protected Areas: Protected Landscapes/Seascapes. IUCN Gland, Switzerland and Cambridge, UK, 122.

Pickering, C., Rossi, S. D., Hernando, A., Barros, A. 2018. Current knowledge and future research directions for the monitoring and management of visitors in recreational and protected areas. Journal of Outdoor Recreation and Tourism 21, 10-18.

Puczkó, L., Rátz, T. 200o. Az attrakciótól az élményig - A látogatómenedzsment módszerei. Geomédia Szakkönyvek, Budapest.

Rátz, T. 2011. Attrakció- és látogatómenedzsment. In: Aubert, A. (Ed.): Turizmus-menedzsment. E-learning paper. http://www.eturizmus.pte.hu/szakmai-anyagok/Turizmusmenedzsment/book.html\#d6e2153 (in Hungarian) (22.03.2018)

Standovár T. 2016. A 2014. decemberi jégtörés hatásainak vizsgálata a Pogány-Rózsás Erdörezervátumban. Research report (in Hungarian) http://karpatierdeink.hu/files/docs/ Kutatasi_jelentes_Pogany_Rozsas_20161031.pdf (19.06.2017)

Swedish EPA, 2015. Outdoor recreation and nature tourism in protected natural environments. Tips, advice and rules for organised activities. Stockholm, 12.

TRC, 2014. Guidelines for trail planning, design and management. TRC Tourism Pty Ltd. 76. Australia. https://www.trctourism.com/portfolio-items/guidelines-for-trail-management-and-infrastructure/ (16.08.2018) 